DOI: https://doi.org/10.15407/techned2018.04 $: 102$

\title{
SELECTIVE COMPENSATION OF THREE-PHASE CURRENT HARMONICS
}

Journal

Publisher

ISSN

Issue

Pages
Tekhnichna elektrodynamika

Institute of Electrodynamics National Academy of Science of Ukraine 1607-7970 (print), 2218-1903 (online)

No 4, 2018 (July/August)

$102-105$

\section{Authors}

S. Peresada*, S. Kovbasa ${ }^{\star *}$, Y. Zaichenko***, V. Reshetnyk ${ }^{\star \star \star *}$

National Technical University of Ukraine "Igor Sikorsky Kyiv Polytechnic Institute", pr. Peremohy, 37, Kyiv, 03056, Ukraine,

e-mail: sergei.peresada@gmail.com

* ORCID ID : http://orcid.org/0000-0001-8948-722X

** ORCID ID : http://orcid.org/0000-0002-2954-455X

*** ORCID ID : http://orcid.org/0000-0002-2933-7737

**** ORCID ID : http://orcid.org/0000-0002-8428-0446

\begin{abstract}
A new nonlinear algorithm for shunt active power filter current control is designed. Proposed solution provides asymptotic current tracking and, unlike existing solutions, does not require "high-gain" control. Such approach simplifies the practical implementation and increases the system noise immunity. Simulation results confirms theoretical findings and demonstrate the effectiveness of the proposed solution for shunt active power filters with selective harmonics compensation. References 7 , figures 2 , table 1.
\end{abstract}


Key words: active power filter, higher-order harmonics, observer.

Received: 02.03 .2018

Accepted: 13.03.2018

Published:

\section{References}

1. Schwanz D., Bagheri A., Bollen M. and Larsson A. Active harmonic filters: Control techniques review, 2016. 17 $7^{\text {th }}$ International Conference on Harmonics and Quality of Power (ICHQP), Belo Horizonte, 2016. Pp. 36-41. DOI:

https://doi.org/10.1109/ICHQP.2016.7783423

2. Ronchi F. and Tilli A. Three-phase positive and negative sequences estimator to generate current reference for selective active filters. IEEE Mediterranean conference on control and automation . MED2002, Lisbon, 2002.

3. Ronchi F., Tilli A. Design methodology for shunt active filters. Proc. $10^{\text {th }}$ EPE-PEMC 2002, Cavtat \& Dubrovnik, Croatia, September 2002.

4. Akagi H., Watanabe E. H., Aredes M. Instantaneous Power Theory and Applications to Power Conditioning , Wiley-IEEE Press, 2017. 472 p. DOI: https://doi.org/10.1002/978111930 7181

5. Liu H., Hu H., Chen H., Zhang L., and Xing Y. Fast and Flexible Selective Harmonic Extraction Methods Based on the Generalized Discrete Fourier Transform. IEEE Trans. Power Electron 2017. Vol. PP. No 99. Pp. 1-1.

6. Fortescue L. Method of Symmetrical Co-Ordinates Applied to the Solution of Polyphase Networks. Transactions of the American Institute of Electrical Engineers. 1918. Vol. XXXVII. No 2. Pp. 1027-1140. DOI:

https://doi.org/10.1109/T-AIEE.1918.4765570 
7. Peresada S., Mykhalskyi V., Zaichenko Y., Kovbasa S. Selective and adaptive harmonics estimation for three-phase shunt active power filters. Tekhnichna Elektrodynamika. 2018. No 2. Pp. 29-38. DOI:

https://doi.org/10.15407/techned2018.02.029

PDF 